\title{
The long-term effectiveness of reactive phosphate rock as a phosphate fertiliser for New Zealand pastures
}

\author{
A.G. Sinclair', C.B. Dyson ${ }^{2}$ \\ and P.W. Shannon ${ }^{3}$ \\ 'Invermay Agricultural Centre, MAFTech, \\ Private Bag, Mosgiel \\ Canterbury Agriculture and Science Centre, \\ MAFTech, P.O. Box 24, Lincoln \\ ${ }^{3}$ Ruakura Agricultural Centre, MAFTech, \\ Private Bag, Hamilton
}

ABSTRACT Sechura reactive phosphate rock (SPR) and triple superphosphate (TSP) have been compared as phosphate fertilisers for pastures in a series of 19 field trials dispersed throughout New Zealand, each continuing for 3-6 years. Both fertilisers were applied annually at 4 rates. In the first 2 years SPR was much less effective at increasing dry matter yields than TSP, but its performance improved markedly with time. In year 6 SPR outyielded TSP at all application rates for all sites combined. The relative performance of SPR and TSP differed markedly at different sites. Very high soil phosphate retention and a combination of low moisture and high $\mathrm{pH}$ appeared to be unfavourable for SPR performance. In most sites SPR was equal or superior to TSP by year 6. SPR substantially raised molybdenum concentration in clovers, and this may have contributed to its superior performance at some sites. As TSP and single superphosphate were equally effective, the good performance of SPR and the relative cheapness of reactive phosphate rocks suggest an important role for the latter on New Zealand pastures.

Keywords Sechura phosphate rock, reactive phosphate rock, RPR, superphosphates, phosphate fertilisers

\section{INTRODUCTION}

In 1982183 the Ministry of Agriculture and Fisheries began a series of 19 field trials to evaluate phosphate fertiliser alternatives to superphosphate, with a view to identifying opportunities to reduce the cost of fertilising pastures. The stimulus for this major undertaking was a series of studies showing promising performances from cheaper alternatives to superphosphate, particularly reactive phosphate rocks (Syers \& Gregg 1981). The MAF series aimed to obtain a nationwide picture of the long-term performance of alternatives and if possible identify and quantify the factors influencing performance so that the suitability of fertilisers for specific situations (soil/climate/production system) could be assessed.
The national series was completed in May 1989 and this paper is the first report covering the full period, although two interim reports have appeared (Quin $\boldsymbol{e t}$ al. 1985; Sinclair \& Dyson 1988).

\section{MATERIALS AND METHODS}

Twelve different phosphatic fertilisers were included in the trial series, but the most detailed comparison was between Sechura phosphate rock (SPR), a reactive phosphate rock from Peru, and triple superphosphate (TSP). That comparison is the subject of this paper. SPR contained $12.8 \%$ total $\mathrm{P}$ and $5.7 \%$ citric acidsoluble $\mathrm{P}$ (analysed without grinding). It was applied unground (60\% passing a $1.50 \mathrm{u} \mathrm{m}$ sieve). TSP contained $20.6 \%$ total $\mathrm{P}, 19.4 \%$ citric acid-soluble $\mathrm{P}$ and $18.8 \%$ water-soluble $\mathrm{P}$.

The fertilisers were compared on well established pastures which had been regularly topdressed with superphosphate at maintenance rates. Maintenance phosphate rates $(\mathbf{M})$ were calculated for each site using the MAF phosphate maintenance model, and SPR and TSP were applied at rates equivalent to $0.5,0.75,1.0$ and $2.0 \mathrm{M}$ calculated on the basis of the total $\mathrm{P}$ content of both materials. There was also a nil phosphate treatment. Applications were made annually throughout the trial. Basal dressings of sulphur, potassium and molybdenum fertiliser were applied as considered necessary to prevent their deficiency.

The 19 trial sites (Table 1) were dispersed throughout the country and represented the major pastoral soils of New Zealand. However, some geographic regions were better represented than others because of the availability or otherwise of appropriate staff in the region. Dry east coast soils were underrepresented, and there were no acid upland soils.

Small-plot trials were used, and managed by mowing, generally with retum of clippings. There were 3 replicates of each treatment in a randomised block design. Total herbage DM was measured at each cut, and soil and herbage chemical parameters were generally measured at least twice a year. Twelve trials $(1-7,13,14,17-19)$ continued for 6 years, $3(9,15$ and 16) stopped after 5 years, and $4(8,10,11,12)$ after 3 years.

\section{RESULTS AND DISCUSSION}

In this paper data presented are confined to annual DM production combined over several or all trial sites.

Mitscherlich response curves were fitted to annual DM yields for TSP and SPR averaged over all sites operational in each year (Figure 1). 
Features of the data include:

(i) SPR was relatively ineffective in year 1 .

(ii) The relative effectiveness of SPR increased rapidly with time.

(iii) By year $6 \mathrm{SPR}$ was giving consistently higher DM yields than TSP at all application rates for all operating sites combined.

Table 1 Trial sites.

\begin{tabular}{|c|c|c|c|c|}
\hline $\begin{array}{l}\text { Site } \\
\text { NO. }\end{array}$ & Location & Soil Group & $\mathrm{pH}$ & $\underset{\text { Retention }}{\mathbf{P}}$ \\
\hline 1 & Puketona (Northland) & $\begin{array}{l}\text { Podzolised Northern Yellow- } \\
\text { Brown Earth }\end{array}$ & 6.0 & 15 \\
\hline 2 & Awarua (Northland) & Northern Brown Granular Glay & 5.6 & 52 \\
\hline 3 & Wellsford (Northland) & Northern Yellow-Brown Earth & 5.9 & 34 \\
\hline 4 & Warkworth (Northland & $\begin{array}{l}\text { d) Fodzolised Northern Yellow- } \\
\text { Brown Earth }\end{array}$ & 5.9 & 22 \\
\hline 5 & Helensville (Northland & d) Yellow-Brown Sand & 6.0 & 37 \\
\hline 6 & Waitoa & Yellow-Brown Loam & 5.7 & 70 \\
\hline 7 & Te Kuiti & Yellow-Brown Loam & 5.8 & 98 \\
\hline 8 & Waikite Valley & Yellow-Brown Pumice & 5.1 & 62 \\
\hline 9 & Meremere (Taranaki) & Yellow-Brown Loam & 5.9 & 95 \\
\hline 10 & Aberfeldy (Wanganui) & $\begin{array}{l}\text { Yellow-Grey / Yellow-Brown } \\
\text { Earth }\end{array}$ & 5.5 & 30 \\
\hline II & $\begin{array}{l}\text { Pongaroa (N.I East } \\
\text { Coast) }\end{array}$ & $\begin{array}{l}\text { Yellow-Grey / Yellow-Brown } \\
\text { Earth }\end{array}$ & 5.9 & 25 \\
\hline 12 & Umutoi (Apiti) & Yellow-Brown Earth & 5.5 & 34 \\
\hline 13 & $\begin{array}{l}\text { Winchmore irrigated } \\
\text { (Canterbury) }\end{array}$ & Yellow-Grey Earth & 5.8 & 25 \\
\hline 14 & $\begin{array}{l}\text { Winchmore dryland } \\
\text { (Canterbury) }\end{array}$ & Yellow-Grey Earth & 6.3 & 25 \\
\hline 15 & $\begin{array}{l}\text { Mawheraiti(S,I. West } \\
\text { Coast) }\end{array}$ & Gley Podzol & 5.2 & 9 \\
\hline 16 & $\begin{array}{l}\text { Arahura Valley (S.I. } \\
\text { West Coast) }\end{array}$ & Gley Recent & 5.6 & 15 \\
\hline 17 & $\begin{array}{l}\text { Woodlands (S.E. } \\
\text { Southland) }\end{array}$ & Southern Yellow-Brown Earth & 5.9 & 50 \\
\hline 18 & Benio (Gore) & $\begin{array}{l}\text { Yellow-Grey /Yellow-Brown } \\
\text { Earth }\end{array}$ & 5.6 & 28 \\
\hline 19 & Manapouri & Yellow-Brown & 5.5 & 75 \\
\hline
\end{tabular}

The performance of SPR improved markedly with time, and this improvement was still continuing in the sixth year. Few other trials of reactive phosphate rock have continued long enough for the time effect to be so fully demonstrated as in this series. Curves are not strictly comparable between years because of the loss of 4 sites after year 3 and a further 3 after year 5 . More detailed examination of the data shows that the relatively small change in the relationship of the SPR and TSP curves between years 3 and 4 is attributable to three discontinued sites being more favourable for SPR than the average of the continuing sites. However, subsequent loss of sites did not distort the later between-year comparisons.

The relative value of two forms of the same fertiliser element can usefully be quantified in terms of the "equivalence ratio" (ER) - the ratio of the quantities of the two fertilisers required to give equal amounts of plant production. At DM production equivalent to 0.75M TSP, the ERs derived from the best-fit curves in Figure 1, and expressed as the ratio of SPR to TSP required to give equal production, are respectively $\sim 4$, $1.89,1.13,1.08,0.85$ and 0.75 for years $1-6$. Thus for the 6-year period $E R \simeq 0.15+3.6 / t$ where $t$ is the trial year. It would be most unwise to extrapolate this relationship beyond year 6 .

While an examination of individual site data is beyond the scope of this paper it is important to state that the performance of SPR relative to TSP did differ greatly between sites. On the dryland Winchmore site (site 14) SPR was almost totally ineffective throughout the trial period. This was by far the driest site in the series and also had the highest $\mathrm{pH}$; these are both factors likely to reduce the rate of $\mathrm{P}$ release from SPR

At two sites of highest $P$ retention (sites 7 and 9, $P$ retention 98 and $95 \%$ repectively) SPR performed less well than at most other sites.

At several sites SPR became considerably more effective than TSP towards the end of the trial period. However, this superiority does not necessarily indicate greater efficiency as a supplier of $\mathrm{P}$ to pastures. Analysis of pasture samples from year 6 has shown that SPR can substantially raise molybdenum concentrations in clover and mixed herbage. Several sites did not receive molybdenum as a basal treatment, as local experience had suggested that it was unnecessary. However, low and possibly deficient molybdenum levels developed in clover in control and TSP plots at some of these sites towards the end of the trials, whereas plots receiving SPR had distinctly higher molybdenum levels. This issue requires considerable further investigation but on present evidence we cannot rule out the possibility that the superiority of SPR to TSP at some sites could be a molybdenum rather than a phosphate effect.

Six of the 12 trials which ran for 6 years either received basal molybdenum or had adequate molybdenum status as indicated by herbage chemical analysis. These were sites $1,6,7,13,14$ and 19 . Excluding the dryland Winchmore site (14), mean response curves for SPR and TSP over the other 5 molybdenum-adequate sites were virtually identical in year 6. These sites had $\mathrm{pH}$ in the range 5.5-6.0.

Other comparisons within the trial series showed virtually no difference between TSP and single superphosphate. SPR was very similar to North Carolina reactive phosphate rock up to year 4 but became superior in years 5 and 6 (possibly due to a molybdenum effect).

The principal conclusions to be drawn from this series of trials are that:

(a) reactive phosphate rock (RPR) is relatively ineffective as a fertiliser compared with superphosphate in the first year following application on a wide range of developed pastures;

(b) after several years of regular use RPR can become as effective as superphosphate in favourable situations;

(c) a combination of high $\mathrm{pH}$ (above 6.0) and low rainfall (less than $800 \mathrm{~mm} /$ year) is very 


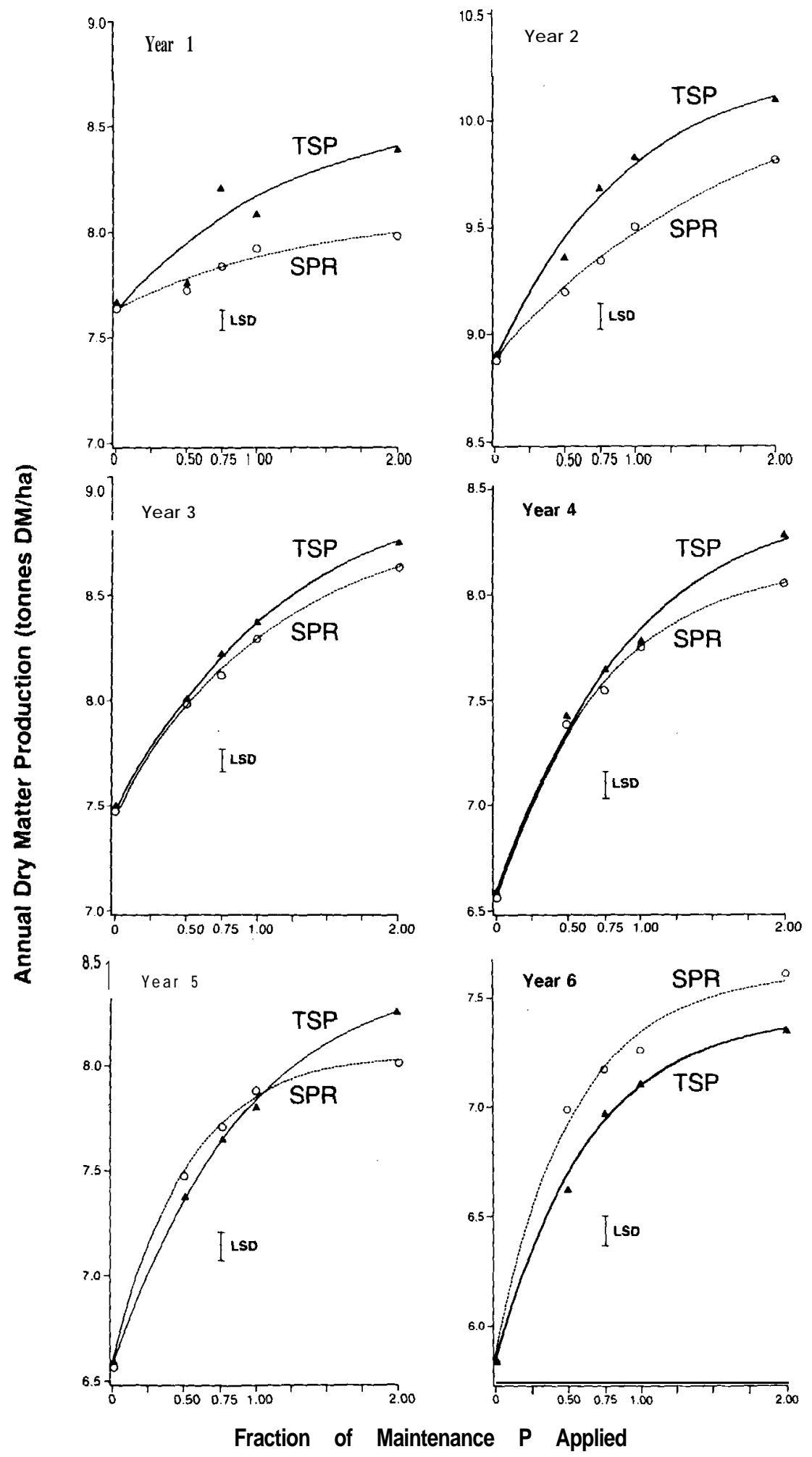

Figure 1 Mean annual response curves for all operating trials in year 1 to year 6. 
unfavourable for RPR, and very high $\mathrm{P}$ retention (95\% or higher) also appears unfavourable;

(d) repeated application of Sechura phosphate rock can significantly raise molybdenum levels in pasture and could be sufficient to overcome molybdenum deficiency.

Acknowledgements This trial series was planned and coordinated mainly by B.F. Quin and conducted by P. Shannon, M. O'Connor, N. Percival, A. Roberts, G. Smith, L. Nguyen, J. Morton and W. Risk.

\section{REFERENCES}

Quin, B.F.; Dyson, C.B.' Shannon, P.W.; O'Connor, MB.; Percival, N.; Roberts, A.; Smith, G.; Nguyen, L.; Williams, P.; Risk, W. 1985. The MAF "National Series" forms of phosphate trials. Proceedings of the 20th Tehnical Conference of New Zealand Fertiliser Manufacturers Research Associations 2: 604-628. Sinclair, A.G.; Dyson, C.B. 1988. An interim report on the MAF "National Series" forms of phosphate fertiliser trials: herbage dry matter production for growing seasons $1982 / 83$ to $1986 / 87$ inclusive. MAFTech, Ministry of Agriculture and Fisheries, Private Bag, Wellington.

Syers, J.K.; Gregg, P.E.H. (Editors) 1981. Proceedings of the Technical Workshop on Potential of phosphate rock as a direct application fertilizer in New Zealand. Occasional report No 3, Department of Soil Science, Massey University, Palmerston North. 